\title{
Analyze of Different Methods of Scarification and Biochemical Composition of Acacia Tortilis Subsp Raddiana Seeds
}

\author{
Salima KEBBAS ${ }^{1,2, *}$, Zahra-Wassila LEKEHAL ${ }^{1,}$, Fatiha AID ${ }^{2}$ \\ ${ }^{1}$ Département de Biologie, Université Saad Dahleb Blida, Algérie \\ ${ }^{2}$ Laboratoire de Biologie et de Physiologie des Organismes- Equipe de physiologie végétale - Faculté \\ des Sciences Biologiques, Université des Sciences et de la Technologie Houari Boumediene (USTHB), \\ Algérie. \\ * corresponding author: selmakebbas@yahoo.fr
}

Bulletin USAMV series Agriculture 72(1)/2015

Print ISSN 1843-5246; Electronic ISSN 1843-5386

DOI 10.15835/buasvmcn-agr: 11152

\begin{abstract}
Acacia totrtilis subsp raddiana or more commonly Acacia raddiana; is one of the few leguminous shrub Saharan, which is of great interest to both ecological and economic.The objective of this work is to study the seed of Acacia raddiana, focusing both germination and its biochemical composition. Different scarification methods were used to lift the inhibition integumentary seed this taxon and hasten germination. We found that manual scarification has allowed obtaining a germination rate calculated at $85 \%$ and a latency of 24 hours. It proves to be the best method, followed by the pure sulfuric acid (98\%). Scarification with boiling water gave poor results with a germination rate of $30 \%$ and a latency 192hours ( 8 days).The study of the biochemical composition of seeds of Acacia raddiana reveals that they are very poor in water (2.82\%), but rich in dry matter (97.18\%), and has an average lipid content (14 085\%). Acacia raddiana seeds are low secondary metabolites: phenolic compounds (687.8 $\mu \mathrm{g} / \mathrm{g}$ dry plant material); flavonoids $(0.339 \mu \mathrm{g} / \mathrm{g}$ dry plant material) and anthocyanins $(2.31 * 10-5 \mathrm{~g} / \mathrm{g}$ dry plant material).
\end{abstract}

Keywords: Acacia raddiana, biochemical composition, germination, integumentary inhibition, scarification.

\section{INTRODUCTION}

Acacia tortilis subsp raddiana; famous tree from Ténéré is native to tropical Africa but thrives in the Sahara, it is particularly strongly present in the edge of the wadi. Formed by trees and shrubs the family of Fabaceae counts more than 1,500 species worldwide including nearly 1,000 in Australia and only 155 species spontaneous in Africa. This species occurs in a wide variety of environmental conditions [1]. Acacia raddiana has many uses. Because of his interest in animal feed and occasionally human (food shortages) and other uses in folk medicine, crafts (mortars, dishes, etc.) and the use of its wood, Acacia raddiana plays a social role and has an economic importance especially for the first indigenous desert regions [2].This socio-economic interest, gives it a special place to be seen in its use in programs rangeland rehabilitation and afforestation in arid and semi arid areas (Jaouadi et al., 2010) [3].

Overwise, any species regeneration have to pass from the study of the optimal conditions of germination.It is in this context that several studies have been done with the aim of better use and improvement of the regeneration process of this taxon. Measures and restoration techniques to be undertaken are still being defined through longterm studies into the dynamics and development of the species. (Jaouadi et al., 2010) [3]. Our present study was conducted as part of 
the contribution to the enhancement of Acacia raddiana in Algeria particularly in the study of the seed in terms of germination and biochemical composition, since it is the starting point regeneration of any plant species.

\section{MATERIAL AND METHODS}

Scarification studies Seeds were scarified according three methods a mechanical one, by using a cuts nail and two chemicals ones using sulfuric acid and boiled water. Fo this purpose, 20 seeds were used for each test and three replicates were made. After disinfection with hypochlorite the seeds treated by each method were placed on a moisted filter paper on a Petri dishes and placed in an oven at $29^{\circ} \mathrm{C}$ in the darkness. Germination was scored daily during eight days.

Biochemical composition, After disinfection, Acacia raddiana seeds were dried in an oven at a temperature between $25^{\circ} \mathrm{C}-28^{\circ} \mathrm{C}$, then ground to obtain a fine powder with an electric mill. One sample of this powder was weighed with a precision balance (Pi). This sample is placed in an oven at a temperature of $70^{\circ} \mathrm{C} \pm 1^{\circ} \mathrm{C}, 3$ hours after, each sample must be weighed. Once the dry weight of the sample is constant (PS), the following equation is established to determine the water content (WC). WC $=(\mathrm{Pi}-\mathrm{PS} / \mathrm{PS}) * 100$ [4]

The powder remaining was used to determine, lipids and secondary metabolites content Polyphenols, flavonoids and anthocyanes were determined according to [5]. All experiments were repeated three times.

\section{RESULTS AND DISCUSSION}

Figure 1 shows the percentage of germination of seeds of Acacia raddiana per day for different treatments: manual scarification (nail section) and the chemical scarification $\mathrm{H} 2 \mathrm{SO} 4$ sulfuric acid and that of boiling water. From the results shown in this figure, the curve of seed germination of Acacia raddiana for each treatment, describes the same pace; with a lag phase of several days, an exponential phase and a stationary phase. Treatment effect was highly significant on the rate and the mean germination time. The results obtained demonstrate the treatment effect at a very important role in seed germination. Our results are close to those reported by of [6] and highlights the need for harsher treatment for Acacia raddiana seeds; this feature is related to the hardness of the seed coat that allows seeds to withstand climate hazards and thereby constitutes insurance for the sustainability of the taxon.

The effectiveness of sulfuric acid (98\%) to raise integumentary inhibition was demonstrated by several authors (Behaeghe et al, 1962. Claworthy 1984; Grouzis 1987; Vora, 1989) [7,8,9,10] but requires a longer contact (one hour or more) to have high germination rate. Soaking the seeds in boiling water gave low germination rate, this is consistent with the results obtained by Grouzis et al. (2003) [11] reported that soaking seeds in water, regardless of its duration and temperature, is of no efficacy to lift the integumentary inhibition.

Comparing our results with those of Kebbas al. (2013) [12]shows that the rate of seed

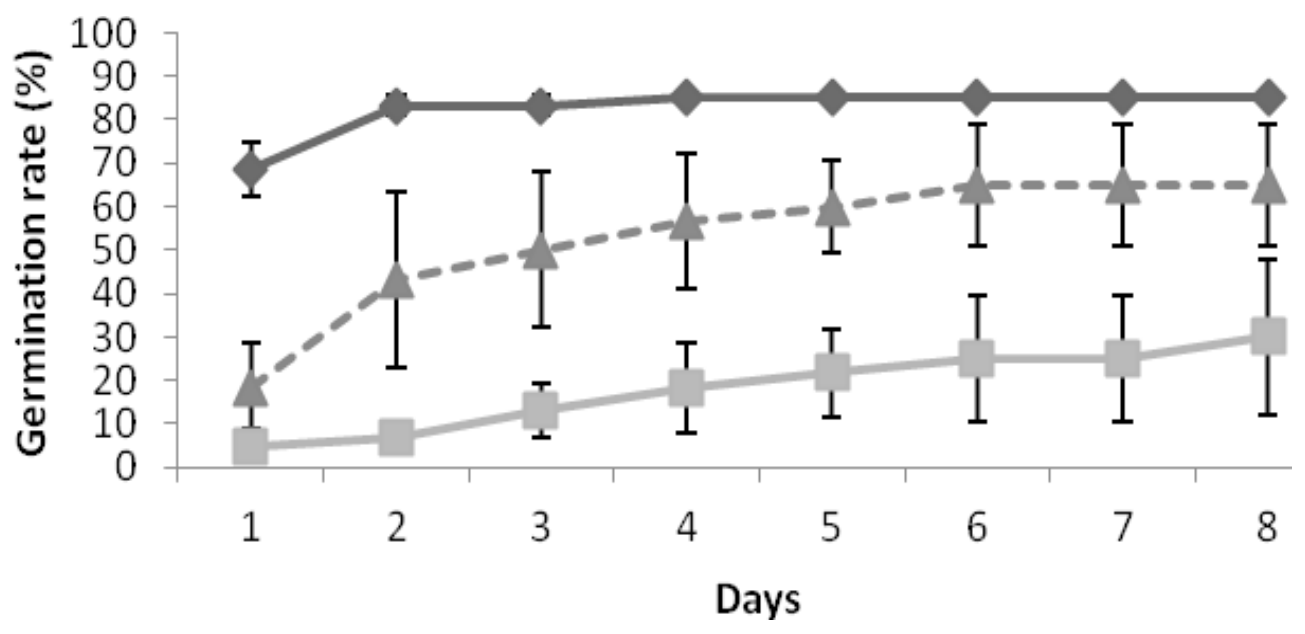

Fig 1. Acacia raddiana kinetic seed germination under different scarification methods (values are means \pm SE of three repetitions) $\rightarrow$ nail cut $\rightarrow-$ boiled water - \pm -sulfuric acid 
germination of Acacia raddiana is slightly lower $(81 \%)$ in conditions of water and osmotic stress. However, in our case we noticed a significant difference both in rate germination and in average time germination (Table 1). In fact, Manual scarification seems to be very efficient and gives a germination rate of $85 \%$ after 03 days. Immersion of the seeds during 30mintes in pure sulfuric acid yielded an average germination rate, which reached $65 \%$ after 06 days. boiling water seems ineffective, only $30 \%$ of seeds germinated during a period of eight days.Other studies have been done on the germination Acacia raddiana seeds using several treatment such as soaking in liquid nitrogen for 2 and 5 days, the germination rate was $45 \%$ and $50 \%$ respectively according to El Saadawi and Abdelwahad (1977) [13]. And even soaking in a rumen fluid collected from animals for 1 and 2 days according to Zohary (1956) [14]; gave a germination rate of $15 \%$ and $20 \%$; a very low rate compared to the results of the manual scarification which is around $85 \%$.

Experiments by Tran (1979) [15]showed that treatment with dry heat at $120^{\circ} \mathrm{C}, 150^{\circ} \mathrm{C}, 200^{\circ}$ $\mathrm{C}$ for 02 hours, is not effective on integumentary inhibition and gave a germination rate lower than $10 \%$. Soaking seeds in pure ethanol for 1day, 3 days and even 5 days gave weak germination rate, that was around $20 \%, 25 \%, 45 \%$ respectively (Chouard 1975 ) [16].

The study of the effect of salt stress found that raising the concentration of sodium chloride $\mathrm{NaCl}$ caused a decrease in rate and mean time to germination at high doses. However, this species tolerates salinity to a concentration of $15 \mathrm{~g} / \mathrm{l}$, for a germination rate of about 55\% (Jaouadi et al., 2010) [3].

Water content is very low in Acacia raddiana seeds and was estimated to $2.82 \pm 0.162 \%$ (Table 2 ). This confirms the hardness of the seed coat in this taxon by the lack of water. However, dry mass was very high and reached $97.18 \% \pm 0.162$. Otherwise, lipid content did not exceeding 15\% that constitute an average value in seeds of Acacia raddiana.

Comparing to others leguminous we clearly notice that the water content in the seeds of Acacia raddiana is 27 times, 21 times, 25 times lower, respectively, in the seeds of beans, chick peas and lentil. On the other hand, for dry matter; we noticide that Acacia raddiana seeds are very rich and arereached 97\%,which allows for better conservation on a much longer duration.

Total polyphenols, total flavonoids and anthocyanins content are expressed respectively as gallic acid quercetin and anthocyandine $\mathrm{C}$-glucoside equivalent, representing an average grade of $687.8 \pm 0.052 \mathrm{mg} / \mathrm{DM}$ for polyphenols, $0.339 \pm 0.046 \mathrm{~g} / \mathrm{DM}$ for flavonoids and $2.31 \pm$ $0.07 * 10-5 \mathrm{mg} / \mathrm{DM}$ in Acacia raddiana seeds. We noticed that polyphenol content in the seeds of Acacia raddiana is low compared to the average content of polyphenols consumed per day in humans (approximately $1 \mathrm{~g}$ ) (Perez-Jimenez et al., 2011) [17], but his virtue against colic sand for animals according Bellakhdar (1978) [18] and

Tab. 1. Average germination rate (mean $\pm S E(n=3)$ ) of Acacia raddiana seeds after three methods of scarifications

\begin{tabular}{cccc}
\hline & $\begin{array}{c}\text { Avrage } \\
\text { germination rate }\end{array}$ & $\begin{array}{c}\text { Time of } \\
\text { germination }\end{array}$ & $\begin{array}{c}\text { Statistical } \\
\text { similtude }\end{array}$ \\
\hline Manual scarification & $85 \% \pm 0$ & 3 days & $\mathrm{A}$ \\
\hline Chemical scarification $\mathrm{H}_{2} \mathrm{SO}_{4}$ & $30 \% \pm 17.80$ & 6 days & $\mathrm{A}$ \\
\hline Boilled Water & $65 \% \pm 14.14$ & 8 days & $\mathrm{B}$ \\
\hline$\left.{ }^{*}\right)$ : Diffrent letters indicate significant différences at $\mathrm{p}<0,05$. Values are & &
\end{tabular}

Tab. 2. Water Content (WC), Dry mass and Lipid Content (mean $\pm \mathrm{SE}$ $(n=3))$ of Acacia raddiana seeds

\begin{tabular}{ccc}
\hline Water Content & Dry Mass content & Lipid Content \\
\hline $2.82 \% \pm 0.162$ & $97.18 \% \pm 0.162$ & $14.085 \%$ \\
\hline
\end{tabular}


Tab. 3. Total polyphenols, Flavonoids and Anthocyanes content (mean $\pm \mathrm{SE}(\mathrm{n}=3))$ in Acacia raddiana seeds

\begin{tabular}{ccc}
\hline \multicolumn{3}{c}{ Polyphenols content in Acacia raddiana seeds/g dry mass } \\
\hline Total polyphenols & Elavonoids & anthocyane \\
\hline $687,8 \pm 0,052 \mu \mathrm{g}$ & $0.339 \pm 0.046 \mu \mathrm{g}$ & $2,31^{*} 10^{-5} \pm 0,07$ \\
\hline
\end{tabular}

against the diarrhea (Hernandez-Pacheco et al., 1949) [19], this explain the frequent use of those taxon seeds as anti-spasmodic.In otherwise, those level are very low comparing to the polyphenol content in leaves that are high and have been estimated to $195.45 \pm 4.16 \mathrm{mg}$ in rosemary leaves, and $2.06 \pm 1.14 \mathrm{mg}$ of flavonoids. The difference in values of secondary metabolites can be explained by the availability of the polyphenols that may change during development of the plant. This may be due to the harsh weather conditions (high temperature, sun exposure, drought, salinity) (Falleh et al., 2008) [20]. Indeed, the phenolic content of a plant depends on a number of intrinsic (genetic) and extrinsic (climatic conditions, cultural practices, maturity at harvest and storage conditions) (Falleh et al, 2008;. Podsedek, 2007) [20,21].

Many authors show that contribution to the antioxidant activity of plant extracts is largely due to the presence of some micronutrients such as polyphenols in general and in particular anthocyanins. The polyphenol content in the seeds of Acacia raddiana is in the middle of the interval (0.046-4.536mg) found according Mbaiogaou al. (2013) [22] on voandzou seeds (Vigna subterranea (L.) As against the anthocyanin content is low in the range $0.331 \mathrm{mg}$.

\section{CONCLUSION}

Manual scarification stays the better, the simplest and the quickest way to lift the integumentary inhibition in Acacia raddiana seeds. Even if other means can be used and are probably very promising as the liquid nitrogene or the microwave method. The low water content in Acacia raddiana seeds seems to able them to be store for a long period without alteration and to be used for their nutritional power; because they are fed during the period of scarcity and long periods of drought, and more once the ground seed, and mixed with wheat flour and water, they prepare their porridge. In spite, a very low polyphenol content, Acacia raddiana seeds exhibit an importance as medicinal plant particulary used for its antioxydant plant, its anti-inflammatory and antispasmodic activity. In conclusion, this taxon stays a key species in those arids region that deserve more and more interest especially for its regeneration.

\section{REFERENCES}

1. Alssadawi IS, Abdelwahad AS (1977). Breaking the dormancy of Acacia farnesiana L. seeds. Bull. Coll. Sci.Univ. Baghdad 48:27-39.

2. Audigie CL, Figurearella J, Zonszain F (1978). Manipulations d'analyses biochimiques. Doin (Ed). Paris : 274.

3. Behaeghe T, Blouard R (1962). Amélioration des semences et sélection des plantes prairiales au Congo, au Rwanda et au Burundi. Bulletin d'information de l'INEAC (9)4.6: 307-338.

4. Bellakhdar J (1997). La pharmacopée marocaine traditionnelle. Paris, Ibis Press :764.

5. Cheema MSZA, Quadir SA (1973). Autoecology of Acacia Senegal L. Willd Vegetatio 27:131 -162.

6. Chourad (1975) in Bensaid S (1991). Germination au laboratoire en conditions naturelles et croissance en minirhizotron de Acacia raddiana Savi in Physiologie des arbres et arbustes en zones arides et semi arides :405-412

7. Claworthy JN (1984). Recherche sur le pâturage au Zimbabwe. Recherche sur l'amélioration des pâturages en Afrique Orientale et austale. Comptes rendus d'un atelier tenu à Harara, Zimbabwe, du 17 au 21 sept. 1984. Publication du CRDI Canada:25-61.

8. Daumont F (1957). J'ai vu l'arbre du Ténéré. Science et Voyage 139:42-47.

9. Falleh H, Ksouri R, Chaieb K, Karray-Bouraoui N, Trabelsi N, Boulaaba M, Abdelly C (2008). Phenolic composition of Cynara cardunculus L. organs, and their biological activities.C R Biol. 2008 May 331(5):372-9.

10. Gast M (1968). Alimentation des populations de l'Ahaggar. Étude ethnographique. Paris, Mémoire Centre d'anthropologie, préhist. ethnogr.Alger (8):475

11. Grouzis M (1987). Structure, productivité et dynamique des systèmes écologiques sahéliens (Mare d'oursi, Burkina Faso). Thèse d'Etat. Université de Paris Sud, Centre d'Orsay:335.

12. Grouzis M, Le Floc'h E (2003). Un arbre au désert Acacia raddiana. IRD Editions, Paris : 313. 
13. Hernandez-Pacheco E, Hernandez-Pacheco F, Alla Medina M, Vidal Box C, Guinea Lopez E (1949). El Sahara Espanol. Estudio geolôgico, geogrilfico y botilnico. Inst. de Estudios Africanos: 808.

14. Jaouadi W, Hamrouni L, Souayeh N, Khouja ML (2010). Étude de la germination des graines $\mathrm{d}>$ Acacia tortilis sous différentes contraintes abiotiques. Biotechnol. Agron. Soc. Environ.14(4):643-652.

15. Kebbas S, Lutts S, Aid F (2013). Contribution to study of Acacia tortilis subsp raddiana seed germination, and growth seedling under different osmotic and drought constraints. Bulletin UASMV serie Agriculture 70(1)/201:227-234.

16. Mbaiogaou A, Hema A, Ouédraogo $M$, Palé E, Naitormbaide M , Mahamout Y et Nacro M (2013). Etude comparative des teneurs en polyphénols et en antioxydants totaux d'extraits de graines de 44 variétés de voandzou (Vigna subterranea (L.)Verdcourt). Int. J. Biol. Chem. Sci. $7(2): 861-871$
17. Pérez-Jiménez J, Fezeu L, Touvier M, Arnault N, Manach C, Hercberg S, Galan P, Scalbert A (2011). Dietary intake of 337 polyphenols in French adults. Am J Clin Nutr.93(6):1220-1228.

18. Podsędek A (2007). Natural antioxidants and antioxidant capacity of Brassica vegetables: A review. LWT 40:1-11.

19. Singleton VL, Rossi IA (1965). Colorimetry of total phenolics with phosphormolybdic- phosphotungstic acid reagents, Am. J. Enol. Viticult. 16:144-158.

20. Tran VN (1979). Towards the optimization on the treatment of some Australian "hardseeds" using in microwave energy. I.M.P.I. Symposium IOWA, 6-9 May:134-137.

21. Vora RS (1989). Seed germination characteristics of selected native plants of the Low Rio. Grande Valley, Texas. Journal of range management 42(1):36-40.

22. Zohary M, Orshansky G (1956). "Wadi araba". Vegetatio 17:15-37. 